\title{
An Ecological Study on Orofacial Clefts in Northeastern Brazil
}

\author{
Alessandro Leite Cavalcanti1 ${ }^{1}$, Everton de Sousa Catão ${ }^{1}$, Tiago Virgínio Fernandes ${ }^{1}$, \\ Natália Medeiros Andrade ${ }^{1}$, Gustavo Correia Basto da Silva², Liege Helena Freitas Fernandes ${ }^{3}$, \\ Catarina Ribeiro Barros de Alencar ${ }^{1}$, Alidianne Fábia Cabral Cavalcanti ${ }^{4}$ \\ ${ }^{1}$ School of Dentistry, State University of Paraiba, Campina Grande, PB, Brazil \\ ${ }^{2}$ MSc Student, Post-graduate Program in Public Health, State University of Paraiba, Campina Grande, PB, Brazil \\ ${ }^{3}$ PhD Student, Post-graduate Program in Dentistry, School of Dentistry, State University of Paraiba, \\ Campina Grande, PB, Brazil \\ ${ }^{4}$ School of Dentistry, State University of Paraiba, Araruna, PB, Brazil
}

\section{SUMMARY}

The objective of this paper was to evaluate the prevalence of live births with orofacial clefts in Northeastern Brazil, with regard to Brazil's federative units. An ecological, descriptive study was developed based on the data recorded in the Brazilian Information System on Live Births (SINASC), between 2011 and 2016 in nine Brazilian capitals (Maceio, Salvador, Fortaleza, São Luís, João Pessoa, Recife, Teresina, Natal and Aracaju). Data on the number of live births, number of live births with congenital anomaly and number of live births with orofacial clefts were collected according to the state of the federation, year of birth, gender, race and birth weight. Data were tabulated with Microsoft Excel software and presented through descriptive statistics (absolute and percentage distributions). In the analyzed period, there were 1,530,701 births, 19,536 (1.3\%) cases of congenital anomalies and 902 cases of orofacial clefts, or 5.9 per 10,000 live births. Among the cities analyzed, Natal (state of Rio Grande do Norte) and Recife (state of Pernambuco) presented the prevalence of 7.3 and 7.2 cases, respectively, of orofacial clefts for every 10,000 births. Regarding the demographic and clinical characteristics, $60 \%$ of children were males, non-white $(83.7 \%)$ and normal birth weight $(73.1 \%)$. In the northeastern region of Brazil, the cities of Natal and Recife presented the highest prevalence of children with orofacial clefts.

Key words: congenital abnormalities, cleft lip, cleft palate, epidemiology

Corresponding author:

Alessandro Leite Cavalcanti

E-mail: alessandrouepb@gmail.com 


\section{INTRODUCTION}

Orofacial clefts (OFC), including cleft lip (CL), cleft palate (CP), and cleft lip and palate (CLP), are among the most common birth defects in the craniofacial region (1). They are congenital anomalies characterized by failures that compromise the fusion between frontonasal and maxillary processes, causing cleft lip and/or fusion of palatal plates of the maxillary process, leading to the development of cleft palate (2). Face embryogenesis occurs around the $8^{\text {th }}$ to $12^{\text {th }}$ week of intrauterine life, providing typical human appearance to the fetus (3); however, this process may be significantly affected by teratogenic agents (drugs, radiation, environmental conditions), as well as by genetic factors that are associated with the chromosomal disposition of each individual, so that cases of malformations may manifest in isolation or associated with syndromes (4).

The etiology of OFC is polygenic and multi-factorial (5). Exposure to risk factors in pregnancy such as alcohol may induce cleft lip and palate. When alcohol is combined with other factors, such as tobacco, drugs, and also other socio-geographic factors, cleft risk is greatly higher (6). Drugs, medicine, corticosteroids, antibiotics and local and general agents used in pregnancy have a great effect on OFC predisposition (6). The environmental factors include maternal illness, infections, drugs, radiation, alcohol, and contamination of food and water with pesticides, nitrates, and mercury (7). The occurrence of these malformations is associated with the geographical region of residence of the family, ethnic characterristics, socioeconomic situation, and exposures to harmful environmental agents in the gestational period (4).

The estimated prevalence of orofacial clefts is 0.36 to 1.56 per 1,000 live births in Brazil in 2012 (8) and affected children tend to suffer from low self-esteem associated with appearance (9), as well as difficulty speaking certain words and from psychological diseases such as depression and anxiety (10). Patients with orofacial clefts also have difficulty in feeding, as their sucking and / or swallowing power becomes limited (11). Moreover, this condition may affect the intellectual development of patients (12) and lead to family problems such as stress and difficulty of acceptance (13).

To treat these patients, a multidisciplinary approach is necessary, with follow-up of physicians, dentists, nutritionists, psychologists, speech therapists, among other professionals (14). The most important dental treatment needs of these patients are: surgical correction of clefts, post-surgical follow-up, oral hygiene instructions and malocclusion treatment (15).
Brazil, through the Ministry of Health, has several health information systems that provide data for analysis and understanding of important health problems that affect the population, supporting decision making by public managers. The Information System on Live Births (SINASC) is among them, which aims to collect data on births registered throughout Brazil and the provision of information on birth rates for all instances of the health system. The system entry document is the Living Birth Declaration, standardized throughout the country.

It is of utmost importance to know the distribution of orofacial clefts for the planning of public policies of care and support to patients with clefts, interfering in a significant way in their quality of life. Therefore, the aim of this study was to evaluate the distribution of the occurrence of orofacial clefts in children born in the northeastern region of Brazil.

\section{MATERIAL AND METHODS}

This study is characterized as being ecological and descriptive. Data were obtained from the Information System on Live Births (SINASC), Department of Informatics of the Unified Health System (DATASUS) between the years 2011 and 2016 in the states of the northeastern region (Paraíba, Bahia, Alagoas, Pernambuco, Sergipe, Rio Grande do Norte, Ceará, Piauí and Maranhão).

Data on the number of live births, number of congenital anomalies, presence of orofacial clefts, year of registration, gender, race and birth weight $(<2.500 \mathrm{~g}$ and $\geq$ $2.500 \mathrm{~g}$ ) were collected. Only live births were included in the analysis. The prevalence of oral cleft rates was calculated by dividing the number of liveborn children with orofacial clefts by the total live births, and then multiplying by 10,000 (1). Data were tabulated using Microsoft Excel software (Microsoft Corporation, Redmond, WA, USA) and presented using descriptive statistics (absolute and percentage distributions).

\section{RESULTS}

The frequency of orofacial clefts was 902 cases in $1,530,701$ live births, which is 5.9 per 10,000 live births. The city with the highest number of cases of live-born children with cleft lip and palate was Recife (22.5\%) (Table 1). The distribution of oral cleft prevalence rates among the capitals showed wide disparities, considering that the highest rate was recorded in Natal (7.3 per 
10,000), whereas the lowest rate was observed in São Luis and Teresina (3.6 per 10,000).

Table 2 shows the distribution of cases according to year of registration, gender, race and birth weight. Re- garding gender, $60 \%$ were male, $83.7 \%$ were non-white and $73.1 \%$ had birth-weight $\geq 2.5 \mathrm{~kg}$. The gender ratio was 1.5:1 (male: female).

Table 1. Distribution of live births with congenital anomalies and orofacial clefts

\begin{tabular}{lcccccc}
\hline \hline \multicolumn{1}{c}{ Brazilian Capitals (State) } & $\begin{array}{c}\text { No. of live } \\
\text { births }\end{array}$ & \multicolumn{2}{c}{$\begin{array}{c}\text { Congenital } \\
\text { anomalies }\end{array}$} & Orofacial clefts & $\begin{array}{c}\text { Prevalence per } \\
\text { 10,000 live births }\end{array}$ \\
\hline Maceio (Alagoas) & 144.595 & 1427 & 7.3 & 73 & 8.1 & 5.0 \\
Salvador (Bahia) & 270.539 & 3754 & 19.2 & 141 & 15.6 & 5.2 \\
Fortaleza (Ceará) & 295.082 & 3315 & 17.0 & 158 & 17.5 & 5.3 \\
São Luís (Maranhão) & 133.070 & 1196 & 6.1 & 48 & 5.3 & 3.6 \\
João Pessoa (Paraíba) & 133.976 & 1575 & 8.1 & 64 & 7.1 & 4.7 \\
Recife (Pernambuco) & 281.368 & 4343 & 22.2 & 203 & 22.5 & 7.2 \\
Teresina (Piauí) & 131.289 & 1169 & 6.0 & 48 & 5.3 & 3.6 \\
Natal (Rio Grande do Norte) & 125.283 & 1138 & 5.8 & 92 & 10.2 & 7.3 \\
Aracaju (Sergipe) & 120.394 & 1619 & 8.3 & 75 & 8.4 & 6.2 \\
\hline Total & $1,530.701$ & 19536 & 100.0 & 902 & 100.0 & \\
\hline \hline
\end{tabular}

Table 2. Distribution of live births with orofacial clefts according to the year, gender, race and birth-weight

\begin{tabular}{lcc}
\hline \hline \multicolumn{1}{c}{ Variables } & $\mathbf{N}$ & \% \\
\hline Year (902) & 151 & 16.7 \\
2011 & 129 & 14.3 \\
2012 & 142 & 15.7 \\
2013 & 152 & 16.9 \\
2014 & 153 & 17.0 \\
2015 & 175 & 19.4 \\
2016 & & \\
Gender (902) & 542 & 60.0 \\
Male & 360 & 40.0 \\
Female & & \\
Race (902) & 147 & 16.3 \\
White & 755 & 83.7 \\
Non-white & & 26.9 \\
Birth-weight (Kg) (902) & 243 & 73.1 \\
$<2.5$ & 659 & \\
$\geq 2.5$ & & \\
\hline \hline
\end{tabular}




\section{DISCUSSION}

Orofacial clefts are craniofacial anomalies of multifactorial origin resulting from defects in the fusion of craniofacial processes (16). The non-syndromic condition is the most prevalent among affected individuals and is one in which cleft is not associated with other malformations or with cognitive alterations (17).

In relation to the distribution of live births with orofacial clefts, the city of Recife (state of Pernambuco) presented the highest percentage of cases, followed by Fortaleza (state of Ceará) and Salvador (state of Bahia). Other Brazilian researchers also found a higher frequency of orofacial clefts in these states of the federation (1).

Surgical correction is the first step in the therapeutic approach of orofacial cleft treatment, and can reduce the aesthetic and functional sequelae (1). Knowing the magnitude of damages of orofacial clefts, their correction as early as possible brings innumerable benefits to patients (2). It is also noteworthy that the reference health units for the treatment of patients with clefts in the northeastern region are located in these states, such as the "Professor Fernando Figueira" Institute of Integral Medicine of Recife (state of Pernambuco), "Albert Sabin" Children's Hospital (Fortaleza, state of Ceará) and "Irmã Dulce" Center for Craniofacial Anomalies (Salvador, state of Bahia).

It was identified that Natal (state of Rio Grande do Norte) and Recife (state of Pernambuco) presented the prevalence of 7.3 and 7.2 cases, respectively, of orofacial clefts for every 10,000 births. The possibility of underreporting of children born alive with orofacial clefts in SINASC (18) may explain the fact that more populous states, such as Bahia, presented a lower proportion of cases when compared to Rio Grande do Norte and Pernambuco. For the continuous improvement of the system, periodic supervision is suggested in order to identify and correct possible data inconsistencies, and the training of those responsible for completing and processing the Live Birth Declaration (19).

Except for the year 2012, an increase in the prevalence of registered cases of orofacial clefts was observed during the following years. It is known that the extrinsic factors to which the mother is exposed exert influence in the development of orofacial clefts (4). Taking into consideration the modern lifestyle, it is suggested that greater exposure to teratogenic factors is related to the increased prevalence of orofacial clefts.

Cleft palate alone is more common in women, while cleft palate and lip is more frequent among males, across various ethnic groups (20). In the present study, most children with clefts were males, corroborating similar results found in literature (2, 20-23). Molecular and genetic studies are needed to better understand the differences between the types of oral clefts and gender (20).

It was possible to verify that the prevalence of cases of orofacial clefts was higher in non-white children (black, brown, yellow and indigenous), with $83.7 \%$ of cases. These data are similar to previously described results (24), where the majority of patients were brown. On the other hand, a study conducted by Brazilian researchers found a higher occurrence in white children (21). The effect of racial miscegenation in Brazil in determining genotype (24) may be a hypothesis for the lack of consensus in literature. Thus, further studies should be performed in order to clarify the existence of a possible association between race and presence of orofacial clefts. However, it is important to mention that non-white individuals do not have unequal rights in the treatment of orofacial clefts, but Brazil is a country with great social inequalities $(25,26)$, where the non-white population is in the lower income social strata, so this group may have less access to Brazil's healthcare system.

The literature shows that the lower birth weight in orofacial clefts cases might be related to the absence or incomplete development of facial tissues (27). In this stu$\mathrm{dy}$, a higher frequency of cases of children with orofacial clefts born with normal weight was identified. This result is consistent with findings of Brazilian $(23,24)$ and Thailand (28) studies which demonstrated that the majority of infants with orofacial clefts had normal birth weight.

The Brazilian Information System on Live Births is a reliable source of information for the analysis of live births with orofacial clefts $(18,23)$. Therefore, considering the prevalence found and the negative impact that this condition implies on the quality of life of these children and family members $(2,29,30)$, the care provided by the government to those born with orofacial clefts should be made in a comprehensive way through the adoption of public health policies directed to this population group. Another measure of extreme relevance includes the implantation of specialized centers of care and rehabilitation to individuals with orofacial clefts.

\section{CONCLUSION}

The occurrence of orofacial clefts was high, particularly in the cities of Natal and Recife, affecting male and white children. 


\section{Acknowledgments}

This study was supported by the National Council for Scientific and Technological Development (CNPq)
- Fellowship of Research Productivity (Process 302850/ 2016-3).

\section{Author Disclosure Statement}

No competing financial interests exist.. 


\section{References}

1. Sousa GFT, Roncalli AG. Orofacial clefts in Brazil and surgical rehabilitation under the Brazilian National Health System. Braz Oral Res 2017; 31:1-10. https://doi.org/10.1590/1807-3107bor-2017.vol31.0023

2. Filgueira IG, Azevedo, ID, Ramalho LS, et al. Quality of life of patients with cleft lip and / or cleft palate: perspective of parents/guardians. Braz Res Pediatr Dent Integr Clin 2015; 15:431-40.

3. Pacáková $\mathrm{D}$, Zábavníková $\mathrm{M}$, Miklosová $\mathrm{M}$, et al. Epidemiological study of orofacial clefts among population of eastern Slovakia during the period 19962013. Cent Eur J Public Health 2016; 24:128-32. https://doi.org/10.21101/cejph.a4131

4. Dixon MJ, Marazita ML, Beaty TH, Murray JC. Clef lip and palate, understanding genetic and environmental influences. Nat Rev Genet 2011; 12:167-78. https://doi.org/10.1038/nrg2933

5. Neogi SB, Singh S, Pallepogula DR, et al. Risk factors for orofacial clefts in India: A case-control study. Birth Defects Res 2017; 109:1284-91.

https://doi.org/10.1002/bdr2.1073

6. Kawalec A, Nelke K, Pawlas K, Gerber H. Risk factors involved in orofacial cleft predisposition review. Open Med 2015; 10:163-75.

https://doi.org/10.1515/med-2015-0027

7. Aylsworth AS, Allori AC, Pimenta LA, et al. Issues involved in the phenotypic classification of orofacial clefts ascertained through a state birth defects registry for the North Carolina Cleft Outcomes Study. Birth Defects Res A Clin Mol Teratol 2015; 103:899903.

https://doi.org/10.1002/bdra.23415

8. Freitas JAS, Neves LT, Almeida ALPF, et al. Rehabilitative treatment of cleft lip and palate: experience of the Hospital for Rehabilitation of Craniofacial Anomalies/USP (HRAC/USP)-Part 1: overall aspects. J Appl Oral Sci 2012; 20:9-15. https://doi.org/10.1590/S1678-77572012000100003
9. Piombino P, Ruggiero F, Dell'Aversana Orabona G, et al. Development and validation of the quality-oflife adolescent cleft questionnaire in patients with cleft and lip palate. J Craniofac Surg 2014; 25:1757-61. https://doi.org/10.1097/SCS.0000000000001033

10. Munz SM, Edwards SP, Inglehart MR. Oral heatlrelated quality of life, and satisfaction with treatment and treatment outcomes of adolescent/young adults with cleft lip/palate: an exploration. Int J Maxillofac Surg 2011; 40:790-6.

https://doi.org/10.1016/j.ijom.2011.03.002

11. Amstalden-Mendes LG, Magna LA, Lopes VLGS. Neonatal care of infants with cleft lip and/or palate: feeding orientation and evolution of weight gain in a nonspecialized Brazilian hospital. Cleft Palate Craniofac J 2007; 44:329-34. https://doi.org/10.1597/05-177

12. Hunt $\mathrm{O}$, Burden $\mathrm{D}$, Hepper $\mathrm{P}$, et al. Parent reports of the psychosocial functioning of children with cleft lip and/or palate. Cleft Palate Craniofac J 2007; 44: 304-11.

https://doi.org/10.1597/05-205

13. Broder HL, Wilson-Genderson M, Sischo L. Examination of a theoretical model for an oral healthrelated quality of life among youths with cleft. Am J Public Health 2014; 104:865-71. https://doi.org/10.2105/AJPH.2013.301686

14. Vanz AP, Ribeiro NRR. Listening to the mothers of individuals with oral fissures. Rev Esc Enferm USP 2011; 45:596-602. https://doi.org/10.1590/S0080-62342011000300007

15. Amobi EO, Mafeni J, Adekoya-Sofowora CA. Perceived and normative needs of facial cleft patients seen in Nigeria. Pesqui Bras Odontopediatria Clin Integr 2018; 18:e3841.

https://doi.org/10.4034/PBOCI.2018.181.13

16. Loffredo LCM, Souza JMP, Freitas JAS, Mossey PA. Oral clefts and vitamin supplementation. Cleft Palate Craniofac J 2001; 38:76-83. 
https://doi.org/10.1597/1545$\underline{156920010380076 \text { ocavs 2.0.co } 2}$

17. Gorlin R, Cohen M, Hennekam R. Syndromes of the head and neck. $4^{\text {th }}$ ed. New York: Oxford University Press, 2001.

18. Santana TM, Silva MDP, Brandão SR, et al. Liveborn infants with cleft lip and/or cleft palate: contribution of speech pathology sciences to Sinasc. Rev CEFAC 2015; 17:485-91. https://doi.org/10.1590/1982-021620158014

19. Silva RS, Oliveira CM, Ferreira DKS, Bonfim CV. Live Birth Information System variable completeness evaluation in the Northeast Brazilian States, 2000 and 2009. Epidemiol Serv Saúde 2013; 22:34752.

20. Martelli DRB, Machado RA, Swerts MSO, et al. Nonsyndromic cleft lip and palate: relationship between sex and clinical extension. Braz J Otorhinolaryngol 2012; 78:116-20. https://doi.org/10.5935/1808-8694.20120018

21. Gardenal M, Bastos PRHO, Pontes ERJC, Bogo D. Predominance of orofacials fissure diagnosed in refference service in resident cases in Mato Grosso do Sul State. Arq Int Ortorrinolaringol 2011; 15:13341.

\section{https://doi.org/10.1590/S1809-48722011000200003}

22. Carvalho PHM, Machado RA, Reis SRA,et al. Parental age is related to the occurrence of cleft lip and palate in Brazil populations. Braz J Oral Sci 2016; 15:167-70.

https://doi.org/10.20396/bjos.v15i2.8648758

23. Andrade NM, Fernandes TV, Catão ES, et al. Prevalence of cleft lip and palate in Brazilian children 2011-2015. Internet J Med Update 2018; 13:10-14. https://doi.org/10.4314/ijmu.v13i1.3
24. Figueiredo CJR, Vasconcelos WKS, Maciel SSSV, et al. Prevalence of oral clefts in the State of Rio Grande do Norte, Brazil, between 2000-2005. Rev Paul Pediatr 2011; 29(1):29-34. https://doi.org/10.1590/S0103-05822011000100005

25. Santos JS, Amaral JHL, Palmier AC, Abreu MHNG. Hospital dental treatment for special health care needs patients in Minas Gerais state, Brazil: A cluster analysis. Pesqui Bras Odontopediatria Clin Integr 2017; 17:e3668. https://doi.org/10.4034/PBOCI.2017.171.49

26. Martins ES, Oliveira EGC, Alves KGL, et al. Oral health of hospitalized Brazilian children: A crosssectional study. Pesqui Bras Odontopediatria Clin Integr 2019; 19: e4423 https://doi.org/0.4034/PBOCI.2019.191.09

27. Wyszynski DF, Sarkozi A, Vargha P, Czeizel AE. Birth weight and gestational age of newborns with cleft lip with or without cleft palate and with isolated cleft palate. J Clin Pediatr Dent 2003; 27:185-90. https://doi.org/10.17796/jcpd.27.2.475367q2601u3x4 $\underline{\mathrm{w}}$

28. McKinney CM, Chowchuen B, Pitiphat W, et al. Micronutrients and oral clefts: a case-control study. J Dent Res 2013; 92:1089-94. https://doi.org/10.1177/0022034513507452

29. Rivaldo EG, Russomano RP, Vargas-Ferreira F, et al. Impact of cleft lip and palate on Oral Health-Related Quality of Life (OHRQOL) in Brazilian patients. Pesqui Bras Odontopediatria Clin Integr 2017; 17: e3609.

https://doi.org/10.4034/PBOCI.2017.171.27

30. Queiroz BM, Alencar NA, Requejo MEP, et al. Risk factors, perception of caregivers and impact of early childhood caries on quality of life related to oral health of preschool children and their families. Braz Res Pediatr Dent Integr Clin 2015; 15:85-94. https://doi.org/10.4034/PBOCI.2015.151.10 


\title{
Ekološka studija o orofacijalnim rascepima u severoistočnom Brazilu
}

\author{
Alessandro Leite Cavalcanti ${ }^{1}$, Everton de Sousa Catão ${ }^{1}$, Tiago Virgínio Fernandes ${ }^{1}$, \\ Natália Medeiros Andrade1, Gustavo Correia Basto da Silva², Liege Helena Freitas Fernandes², \\ Catarina Ribeiro Barros de Alencar ${ }^{1}$, Alidianne Fábia Cabral Cavalcanti ${ }^{4}$ \\ ${ }^{1}$ Stomatološki fakultet, Državni Univerzitet Paraiba, Campina Grande, PB, Brazil \\ ${ }^{2}$ Student magistarskih studija, Program postdiplomskih studija javnog zdravlja, Državni Univerzitet Paraiba, \\ Campina Grande, PB, Brazil \\ ${ }^{3}$ Student doktorskih studija, Program postdiplomskih studija stomatologije, Stomatološki fakultet, \\ Državni Univerzitet Paraiba, Campina Grande, PB, Brazil \\ ${ }^{4}$ Stomatološki fakultet, Držauni Univerzitet Paraiba, Araruna, PB, Brazil
}

\section{SAŽETAK}

Cilj studije bila je procena prevalencije živorođene dece sa orofacijalnim rascepima $\mathbf{u}$ severoistočnom Brazilu, po federativnim jedinicama. Urađena je ekološka i deskriptivna studija na osnovu podataka Brazilskog informativnog sistema o živorođenoj deci (Brazilian Information System on Live Births (SINASC)), u periodu od 2011. do 2016. godine u devet glavnih gradova brazilskih saveznih država (Maceio, Salvador, Fortaleza, São Luís, João Pessoa, Recife, Teresina, Natal and Aracaju). Podaci o broju živorođene dece, broju živorođene dece sa kongenitalnom anomalijom i broju živorođene dece sa orofacijalnim rascepima sakupljeni su po državama federacije, godini rođenja, polu, rasi i porođajnoj težini. Podaci su prikazani pomoću programa Microsoft Excel i obrađeni su deskriptivnom statistikom (apsolutna i procentualna podela). $U$ analiziranom periodu zabeleženo je 1.530.701 rođenje, 19.536 (1,3 \%) dece sa kongenitalnim anomalijama i 902 slučaja sa orofacijalnim rascepima odnosno 5,9 dece na $\mathbf{1 0 . 0 0 0}$ živorođene dece. Prema analiziranim gradovima, u Natalu (država Rio Grande do Norte) i Recifeu (država Pernambuco) zabeležena je prevalencija od 7,3 i 7,2 slučaja orofacijalnih rascepa na 10.000 rođene dece. Što se tiče pola dece, $60 \%$ dece bilo je bele rase, $83,7 \%$ ostale rase; normalna porođajna težina zabeležena je kod 73,1 $\%$ dece. U severoistočnoj regiji Brazila, u gradovima Natal i Rectife zabeležena je najveća prevalencija dece sa orofacijalnim rascepima.

Ključne reči: kongenitalne anomalije, rascep usne, rascep nepca, epidemiologija 